\title{
Salt tolerance underlies the cryptic invasion of North American salt marshes by an introduced haplotype of the common reed Phragmites australis (Poaceae)
}

\author{
Edward A. Vasquez ${ }^{1}$, Edward P. Glenn ${ }^{1, *}$, J. Jed Brown ${ }^{2}$, Glenn R. Guntenspergen ${ }^{3}$, \\ Stephen G. Nelson ${ }^{1}$ \\ ${ }^{1}$ Environmental Research Laboratory, 2601 East Airport Drive, Tucson, Arizona 85706, USA \\ ${ }^{2}$ Delaware River Fisheries Coordinator, US Fish and Wildlife Service, 2610 Whitehall Neck Road, Smyrna, \\ Delaware 19977, USA \\ ${ }^{3}$ US Geological Survey, USGS Patuxent Wildlife Research Center, 12100 Beech Forest Road, Suite 4039, Laurel, \\ Maryland 20708-4039, USA
}

\begin{abstract}
A distinct, non-native haplotype of the common reed Phragmites australis has become invasive in Atlantic coastal Spartina marshes. We compared the salt tolerance and other growth characteristics of the invasive $M$ haplotype with 2 native haplotypes ( $\mathrm{F}$ and $\mathrm{AC}$ ) in greenhouse experiments. The $\mathrm{M}$ haplotype retained $50 \%$ of its growth potential up to $0.4 \mathrm{M} \mathrm{NaCl}$, whereas the $\mathrm{F}$ and $\mathrm{AC}$ haplotypes did not grow above $0.1 \mathrm{M} \mathrm{NaCl}$. The $\mathrm{M}$ haplotype produced more shoots per gram of rhizome tissue and had higher relative growth rates than the native haplotypes on both freshwater and saline water treatments. The M haplotype also differed from the native haplotypes in shoot water content and the biometrics of shoots and rhizomes. The results offer an explanation for how the $M$ haplotype is able to spread in coastal salt marshes and support the conclusion of DNA analyses that the M haplotype is a distinct ecotype of $P$. australis.
\end{abstract}

KEY WORDS: Salinity tolerance - Invasive species • Phragmites australis $\cdot$ Salt marshes

Resale or republication not permitted without written consent of the publisher

\section{INTRODUCTION}

A cryptic, invasive haplotype of the common reed Phragmites australis, introduced to North America from populations in Eurasia, has been implicated in the spread of this species into salt marshes that are normally dominated by the perennial salt-tolerant grass Spartina alterniflora (Lynch \& Saltonstall 2002, Salton-

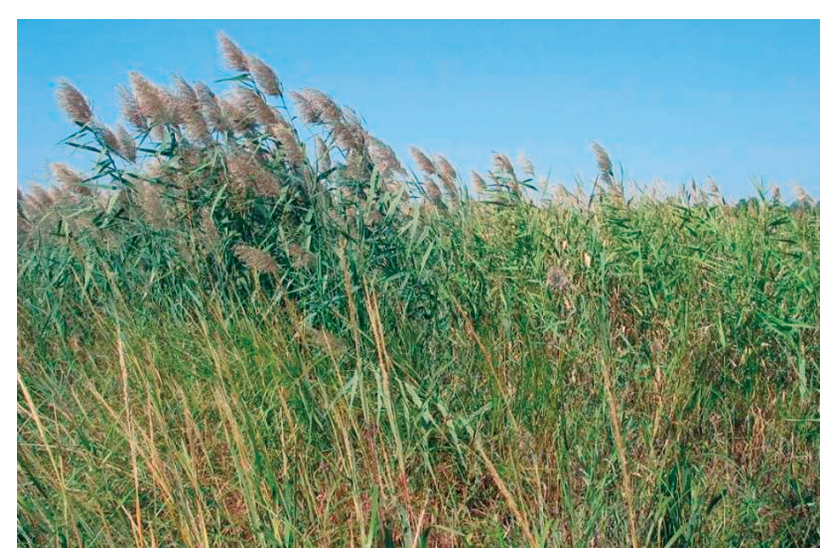

The invasive, M haplotype of Phragmites australis overtopping the shorter, lighter green native form in the Delaware Estuary, USA. The M haplotype, a distinct variety introduced from Europe, has greater salt tolerance and greater ability to generate new shoots from rhizomes than native haplotypes.

Photo: Bob Meadows, Delaware Department of Natural Resources and Environmental Control

stall 2002, 2003a,b). P. australis is a tall (to over $4 \mathrm{~m}$ ), emergent grass found in wetlands around the world (Cronk \& Fennessy 2001). Although this species is native to North America, it is only within the past $30 \mathrm{yr}$ that it has become invasive in Atlantic coastal salt marshes (Chambers et al. 2003, Havens et al. 2003, Lathrop et al. 2003, Weinstein et al. 2003, Weis \& Weis 2003). The spread of $P$. australis into brackish Spartina 
marshes alters their ecological functions and has become a major concern to natural resource managers (Able \& Hagan 2003, Able et al. 2003, Currin et al. 2003, Ravit et al 2003, Rooth et al. 2003, Weis et al. 2003, Widham \& Meyerson 2003).

Phragmites australis is generally considered to be less salt-tolerant than Spartina alterniflora (Glenn 1987, Bart \& Hartman 2003, Burdick \& Konisky 2003), and it has been proposed that the recent invasions are related to salinity reductions associated with human alterations of habitat, such as directing storm runoff into the backs of marshes (Bart \& Hartman 2003, Weis \& Weis 2003, Silliman \& Bertness 2004). However, the role of the exotic Eurasian P. australis haplotype in the invasions raises another possibility: that physiological characteristics of the introduced haplotype differ from those of the native haplotypes, allowing the invasion of saline habitats. To test this hypothesis, we compared the salinity tolerance and growth characteristics of the introduced haplotype of $P$. australis with those of 2 native haplotypes in replicated greenhouse experiments.

\section{MATERIALS AND METHODS}

Source of germplasm and initial propagation of plants. Rhizome sections (several hundred per haplotype) of Phragmites australis were collected in September and November 2003 from reed populations in Delaware and Maryland and shipped to Tucson, Arizona, USA. The populations sampled were among those originally sampled by Saltonstall (2002), who provided detailed directions by which we relocated the collection sites (K. Saltonstall pers. comm.). The haplotypes can be morphologically distinguished in the field (Saltonstall 2004). Samples included rhizome sections of 2 native haplotypes ( $\mathrm{F}$ and $\mathrm{AC}$ ) and of the introduced haplotype (M). The F and AC haplotypes were identified by Saltonstall (2002) as non-expanding populations, whereas the $\mathrm{M}$ haplotype was considered invasive. The $M$ and $F$ accessions were growing in adjacent stands (within $100 \mathrm{~m}$ ) in the Appoquinimink River, in New Castle County, Delaware (39 $26.578^{\prime} \mathrm{N}$, $\left.75^{\circ} 39.601^{\prime} \mathrm{W}\right)$, southeast of the town of Odessa. The site is an oligohaline tidal marsh that drains into the Delaware Estuary. The AC accession was growing in Tuckahoe Creek ( $38^{\circ} 53.116^{\prime}$ N, $\left.75^{\circ} 56.585^{\prime} \mathrm{W}\right)$, in Talbot County, Maryland, south of the town of Hillsboro, in a tidal, low salinity portion of the river that drains into the Choptank River and then into the Chesapeake Bay. Both the M/F and AC sites are located on the Delmarva Peninsula, on the Atlantic coastal plain, and the 2 sites are located approximately $70 \mathrm{~km}$ apart. Within $24 \mathrm{~h}$ after receipt of specimens, rhizome sections were planted in $4 \mathrm{l}$ pots with a mixture (2:1 by volume) of washed sand and peat. The pots were then placed in random order on a greenhouse bench under sprinkler irrigation with freshwater. Approximately 150 pots each of $\mathrm{M}$ and $\mathrm{F}$ haplotype and 30 of the AC haplotype were started.

The greenhouse allowed $85 \%$ penetration of photosynthetically active radiation. Temperature, controlled with evaporative cooling (summer) and electric heating (winter), was maintained between $20^{\circ} \mathrm{C}$ (night lows) and $32^{\circ} \mathrm{C}$ (daytime highs). Plants were watered 3 times daily, so the soil was continually wet. Each was fertilized with slow release fertilizer (Grow More 20-20-20, More Grow Inc.) and a minor element mix (Black Leaf 15\% granular iron plus chelator). Plants were grown for 5 mo under these conditions until used for the experimental growth trials. By this time, plants had initiated numerous new shoots, which had grown to 1-2 m height.

Salinity experiment. In May 2004, sections of mature rhizomes from $\mathrm{F}, \mathrm{M}$, and $\mathrm{AC}$ haplotypes were planted individually in $4 \mathrm{l}$ pots, each containing a 2:1 mixture of washed sand and peat. Forty rhizome sections, similar in mass (mean fresh weight $=5.02 \mathrm{~g}$, standard error of the mean $[\mathrm{SEM}]=0.4 \mathrm{~g}$ ) and with at least 1 visible shoot initial, were planted for each haplotype. Pots were placed under sprinkler irrigation (freshwater) and the rhizomes propagated for $12 \mathrm{~d}$.

On May 20, 2004, 25 pots of each haplotype were randomly selected from the newly propagated rhizomes and placed into 5 randomized blocks, each with 5 pots of each haplotype, along a section of a greenhouse bench. This design was used because there is a slight temperature gradient in the greenhouse. Each pot had only 1 shoot above the soil line at the start of the experiment. Within each block and haplotype, each plant was randomly assigned to irrigation treatment: 0, 0.09, 0.18, 0.27, or $0.36 \mathrm{M} \mathrm{NaCl}$ (5 plants/haplotype/salinity/block). Salinity treatments were made up by adding $\mathrm{NaCl}$ to municipal water (ca. 250 ppm total dissolved solids). Each pot was irrigated every other day with 11 , which was sufficient to produce approximately $850 \mathrm{ml}$ of drainage from each pot. Each pot was fertilized every 2 wk with Grow More (20-20-20) fertilizer. The salinity of the drainage water from each pot was measured with an electrical conductivity meter (Markson) calibrated against $\mathrm{NaCl}$ standards made up for each treatment salinity, and interstitial salinity was calculated as the mean of the irrigation and drainage salinities.

Survival was scored for each pot at the end of the experiment, based on the presence of 1 or more green shoots. Plants that did not survive to the end of the experiment were omitted from the growth analyses (i.e. were not counted as zero values). For each pot, maximum plant height, as distance from the rim of the pot to the tip of the tallest shoot, and number of emergent shoots were measured weekly. After $56 \mathrm{~d}$ of 
growth, plants were harvested, and both the roots and shoots were weighed fresh. Each sample was then dried to constant weight in a solar drier, and its dry mass ( $g$ ) determined. Relative growth rate (RGR) of aboveground tissue was calculated from the final dry weight and the initial weight by the formula:

$\operatorname{RGR}\left(\% \mathrm{~d}^{-1}\right)=100 \times\left(\operatorname{lnWeight}_{\text {final }}-\ln \mathrm{Weight}_{\text {initial }}\right) / 56 \mathrm{~d}$

Initial dry mass was estimated from a sample of shoots taken from extra pots of each haplotype at the beginning of the experiment.

An analysis of cations and anions in shoot tissues was conducted by IAS Laboratories (Phoenix, AZ) on 2 live specimens randomly selected from each treatment at the end of the study. All aboveground tissue in each pot was ground for analysis. The molar concentration of $\mathrm{Na}^{+}$plus $\mathrm{K}^{+}$was calculated for the shoot tissue (assuming they were balanced by anions and were completely dissociated and uniformly dissolved in the tissue water) (Glenn 1987, Matoh et al. 1988).

\section{RESULTS}

\section{Growth characteristics of haplotypes}

The haplotypes exhibited different growth characteristics under common garden conditions in the greenhouse. Fig. 1 shows typical plants from which rhizome sections were taken to begin the salinity trial.

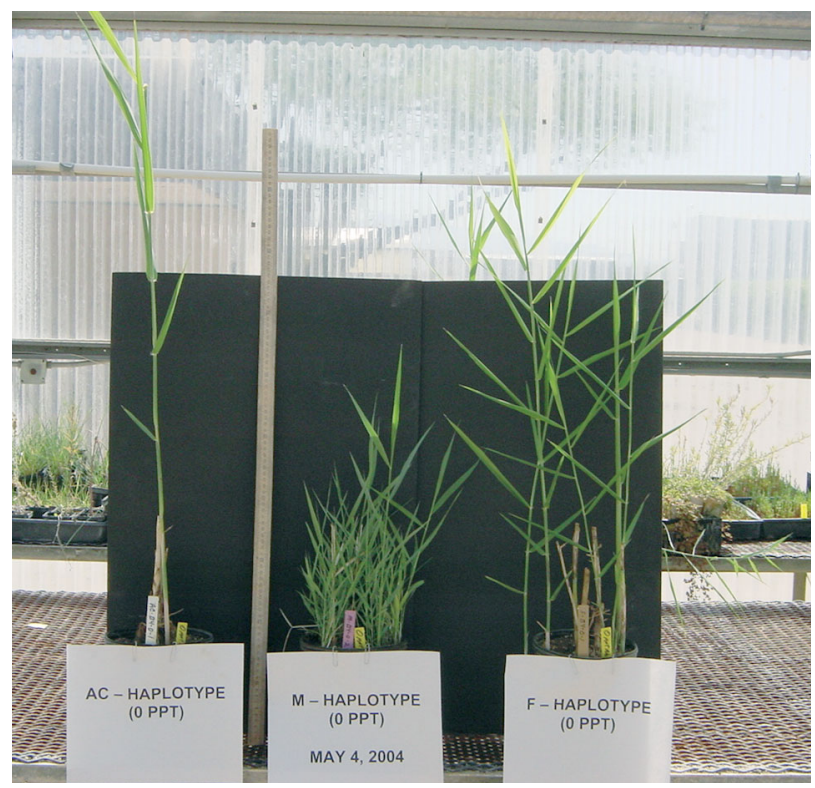

Fig. 1. Phragmites australis. Typical shoot growth produced from rhizomes of $\mathrm{M}, \mathrm{F}$, and AC haplotypes grown under common garden conditions in a greenhouse in Tucson, Arizona, USA. Plants selected from those from which rhizome sections were obtained to start the salinity experiment
The $M$ haplotype tended to produce numerous new shoots from rhizomes, whereas the F haplotype produced fewer, but thicker and taller, shoots, and the AC haplotype in most cases produced only 1 or 2 tall shoots from the original rhizome planting in each pot. These differences persisted over time, and the haplotypes were easily distinguished from each other even after growing for a year in the greenhouse.

\section{Salinity trial}

Drainage water salinities were approximately 20 to $25 \%$ higher than irrigation salinities, because salts unavoidably concentrated in the soil solution between irrigations. Therefore, mean salinities calculated for the pots were 10 to $15 \%$ higher than irrigation salinities. Pot salinities compared to treatment salinities were $0.02 \mathrm{M}$ $\mathrm{NaCl}$ for the $0.0 \mathrm{M} \mathrm{NaCl}$ treatment, $0.13 \mathrm{M} \mathrm{NaCl}$ for the $0.09 \mathrm{M} \mathrm{NaCl}$ treatment, $0.22 \mathrm{M} \mathrm{NaCl}$ for the $0.18 \mathrm{M} \mathrm{NaCl}$ treatment, $0.32 \mathrm{M} \mathrm{NaCl}$ for the $0.27 \mathrm{M} \mathrm{NaCl}$ treatment, and $0.40 \mathrm{M} \mathrm{NaCl}$ for the $0.36 \mathrm{M} \mathrm{NaCl}$ treatment. Pot salinities are used to designate salinity levels in the tables and figures. The $\mathrm{M}$ haplotype had higher survival across the salinity range than the $\mathrm{F}$ and $\mathrm{AC}$ haplotypes (Table 1) ( $p=0.02$ by Friedman's non-parametric test). Both the $\mathrm{F}$ and $\mathrm{AC}$ haplotypes failed to survive above 0.13 and $0.32 \mathrm{M} \mathrm{NaCl}$, respectively, while the $\mathrm{M}$ haplotype survived up to $0.40 \mathrm{M} \mathrm{NaCl}$.

Results of a 2-way ANOVA on the effects of haplotype and salinity on growth parameters and water content are in Table 2. Only the 0.02 and $0.13 \mathrm{M} \mathrm{NaCl}$ salinities, for which survival was high for all haplotypes, were included in the ANOVA. In general, both salinity and haplotype affected growth and water content, but the interaction terms were not significant. Graphs of results across all salinities are in Figs. 2 \& 3 .

Haplotypes grown on $0.02 \mathrm{M} \mathrm{NaCl}$ did not differ significantly in plant height after $7 \mathrm{wk}$. All haplotypes grew to a height of approximately 60 to $70 \mathrm{~cm}$ on $0.02 \mathrm{M} \mathrm{NaCl}$, but the $\mathrm{F}$ and $\mathrm{AC}$ haplotypes did not grow to more than $5 \mathrm{~cm}$ height above $0.22 \mathrm{M} \mathrm{NaCl}$, whereas the $\mathrm{M}$ type grew to $20 \mathrm{~cm}$ even on $0.40 \mathrm{M}$

Table 1. Phragmites australis. Survival of haplotypes (M, F, and $\mathrm{AC}$ ) on different salinities, calculated based on survival after 7 wk (initial $n=5$ )

\begin{tabular}{|lrcr|}
\hline $\begin{array}{l}\text { Salinity } \\
(\mathrm{M} \mathrm{NaCl})\end{array}$ & $\mathrm{M}$ & $\begin{array}{c}\text { Survival (\%) } \\
\text { F }\end{array}$ & $\mathrm{AC}$ \\
\hline 0.02 & 80 & 80 & 80 \\
0.13 & 100 & 20 & 40 \\
0.22 & 100 & 0 & 20 \\
0.32 & 100 & 0 & 40 \\
0.40 & 100 & 0 & 0 \\
\hline
\end{tabular}


Table 2. Phragmites australis. Results of 2-way ANOVA for F, M, and AC haplotypes grown on 0.02 and $0.13 \mathrm{M} \mathrm{NaCl}$. Dependent variables were plant height $(\mathrm{cm})$, number of shoots, relative growth rate (RGR), rhizome dry weight (g), the ratio of shoot dry weight to rhizome dry weight (Sh:Rh), and water content $(\mathrm{g})$ in the aboveground tissues. Independent variables were haplotype $(\mathrm{H})$ and salinity $(\mathrm{S})$. The table gives the F-ratio and p-values for Haplotype, Salinity, and the interaction term $(\mathrm{H} \times \mathrm{S})$

\begin{tabular}{|c|c|c|c|c|c|c|}
\hline & Height & $\begin{array}{l}\text { No. of } \\
\text { shoots }\end{array}$ & RGR & $\begin{array}{l}\text { Rhizome } \\
\text { dry wt. }\end{array}$ & Sh:Rh & $\begin{array}{c}\text { Water } \\
\text { content }\end{array}$ \\
\hline \multicolumn{7}{|c|}{ Haplotypes } \\
\hline$F$ & 1.1 & 13 & 31 & 5.0 & 7.0 & 12 \\
\hline $\mathrm{p}$ & 0.33 & 0.000 & 0.000 & 0.022 & 0.007 & 0.001 \\
\hline \multicolumn{7}{|c|}{ Salinity } \\
\hline F & 8.5 & 33 & 9.4 & 13.7 & 1.2 & 16 \\
\hline $\mathrm{p}$ & 0.000 & 0.000 & 0.000 & 0.002 & 0.28 & 0.000 \\
\hline \multicolumn{7}{|c|}{$\mathrm{H} \times \mathrm{S}$} \\
\hline$F$ & 1.7 & 1.1 & 1.5 & 0.15 & 0.9 & 1.1 \\
\hline $\mathrm{p}$ & 0.12 & 0.37 & 0.19 & 0.87 & 0.43 & 0.37 \\
\hline
\end{tabular}

$\mathrm{NaCl}$ (Fig. 2a). The M haplotype produced more shoots than the native haplotypes and shoot initiation was less affected by salinity for the $M$ haplotype than for the native haplotypes (Fig. 2b). At end of the experiment the $M$ haplotype had a mean of 14 (SEM = 3.5) shoots per pot compared to just 4 and 2 (SEMs $=1.0$, $0.7)$ shoots for the F and AC haplotypes, respectively, on the control treatment. The $\mathrm{M}$ haplotype retained the ability to initiate new shoots up to $0.40 \mathrm{M} \mathrm{NaCl}$, whereas the $\mathrm{F}$ and $\mathrm{AC}$ haplotypes did not initiate new shoots above $0.13 \mathrm{M}$ $\mathrm{NaCl}$.

The $M$ haplotype had higher RGRs than the native haplotypes across the salinity range (Fig. 2c). The $\mathrm{M}$ haplotype retained about $50 \%$ of its growth potential up to $0.40 \mathrm{M} \mathrm{NaCl}$, whereas the other haplotypes failed to grow above $0.13 \mathrm{M}$ $\mathrm{NaCl}$.

The water content of rhizomes harvested at the end of the experiment were not affected by haplotype or salinity, and averaged $4.33 \mathrm{~g} \mathrm{H}_{2} \mathrm{O} \mathrm{g}^{-1}$ dry wt (SEM = 0.24). Dry mass of rhizomes per pot decreased with salinity for all haplotypes, but the $\mathrm{M}$ haplotype had greater rhizome dry mass than the other haplotypes at all salinities (Fig. 2d). On freshwater, the M haplotype produced 1.63 shoots $\mathrm{g}^{-1}$ dry mass of rhizome tissue (SEM $=0.25)$, compared to 0.52 shoots $\mathrm{g}^{-1}(\mathrm{SEM}=0.17)$ and 0.92 shoots $\mathrm{g}^{-1}(\mathrm{SEM}=0.08)$ for the $\mathrm{F}$ and AC haplotypes, respectively.

\section{Water content and mineral concentrations in shoot tissues}

The $M$ haplotype had lower water content than the AC and F haplotypes, and all haplotypes showed a reduction in tissue water on the $0.13 \mathrm{M} \mathrm{NaCl}$ treatment relative to water content on $0.02 \mathrm{M} \mathrm{NaCl}$ (Fig. 3a). Over the range of 0.02 to $0.40 \mathrm{M} \mathrm{NaCl}$, the $\mathrm{M}$ haplotype showed a steady decrease in tissue water from 2.3 to $1.5 \mathrm{~g} \mathrm{~g}^{-1}$ dry weight.

Cation and anion contents of shoots on 0.02 and $0.13 \mathrm{M} \mathrm{NaCl}$ treatments were similar among the haplotypes but were affected by salinity in some cases (Table 3). All 3 haplotypes showed increases in $\mathrm{Na}^{+}$and $\mathrm{Na}: \mathrm{K}$ ratios and decreases in $\mathrm{K}^{+}, \mathrm{Mg}^{++}$ and $\mathrm{Ca}^{++}$on $0.13 \mathrm{M} \mathrm{NaCl}$ compared to the $0.02 \mathrm{M}$ $\mathrm{NaCl}$ treatment. Molarity of the cell sap based on $\mathrm{Na}^{+}$and $\mathrm{K}^{+}$was directly related to the $\mathrm{NaCl}$ content of the external solution (Fig. 3b). Molarity of the cell sap was proportional to the external salinity for all haplotypes up to $0.13 \mathrm{M} \mathrm{NaCl}$, and for the $M$ haplotype across the whole range of salinities.
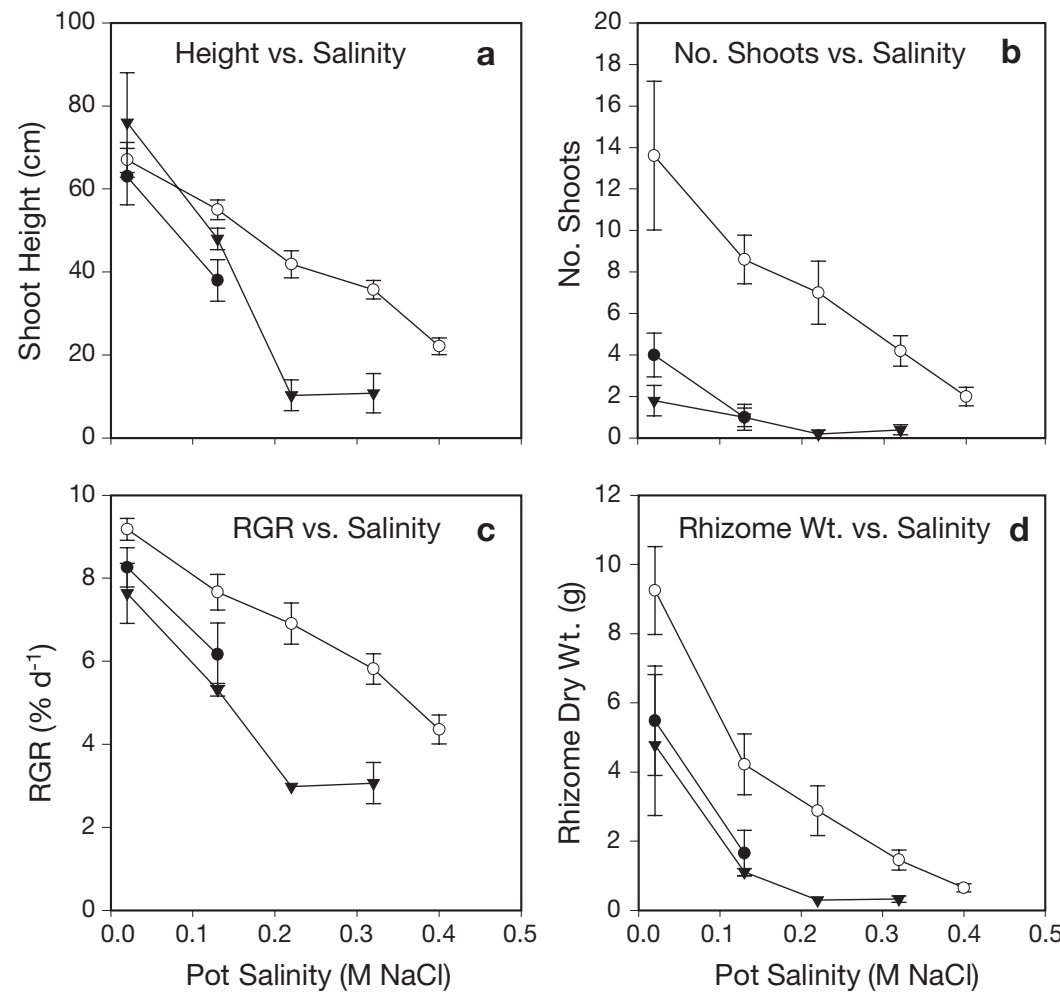

Fig. 2. Phragmites australis. Growth of shoots of haplotypes at different salinities, showing (a) maximum plant height $(\mathrm{cm})$, (b) number of shoots per pot, (c) relative growth rate (RGR), and (d) dry mass (g) of rhizomes over the experiment. F, M, and AC haplotypes are shown by $(\bullet),(0)$, and $(\mathbf{v})$, respectively. Salinities plotted on the $x$-axis are estimates of actual salinities in the pots. Error bars are \pm SEM 

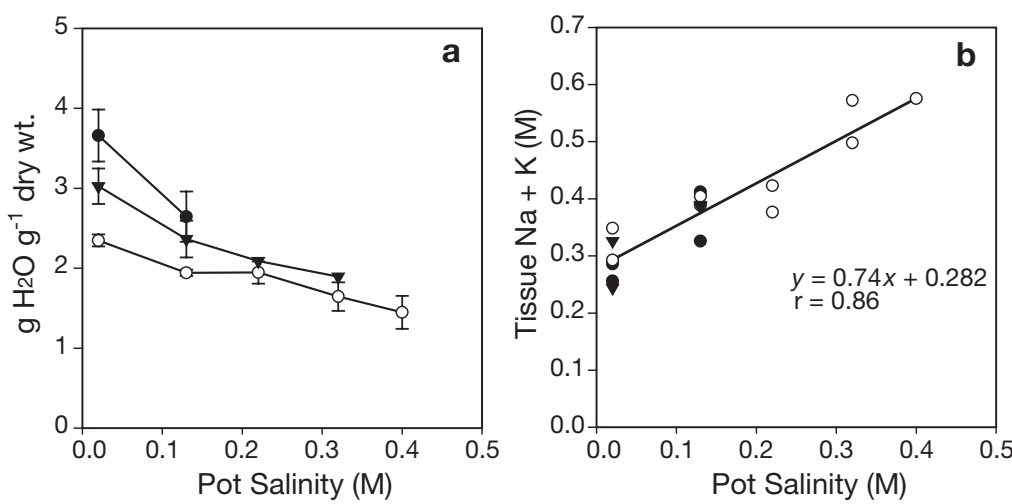

Fig. 3. Phragmites australis. (a) Water content of haplotypes grown at different salinities, and (b) molar concentration of $\mathrm{Na}+\mathrm{K}$ in the shoots tissues vs. $\mathrm{NaCl}$ in the soil solution. F, M, and AC haplotypes are shown by $(\bullet),(0)$, and $(\boldsymbol{\nabla})$, respectively. Salinities plotted on the $x$-axis are estimates of actual salinities in the pots. Error bars are SEM

Table 3. Phragmites australis. Elemental analysis (\% of dry mass) of shoot tissues of haplotypes (M, F, and AC) grown at 2 different salinities (0.02 and $0.13 \mathrm{M} \mathrm{NaCl}$ ). Values are means of 2 different plant samples per treatment. Two-way ANOVAs for each element and the Na:K ratio showed that haplotype was not significant for any element but that salinity was significant for those elements marked by an asterisk

\begin{tabular}{|lcccccccc|}
\hline $\begin{array}{l}\text { Haplotype } \\
\text { salinity }\end{array}$ & $\mathrm{N}$ & $\mathrm{P}$ & $\mathrm{K}^{*}$ & $\mathrm{Ca}^{*}$ & $\mathrm{Mg}^{*}$ & $\mathrm{~S}$ & $\mathrm{Na}^{*}$ & $\mathrm{Na}: \mathrm{K}^{*}$ \\
\hline $\mathbf{M}$ & & & & & & & & \\
$\quad 0.02$ & 3.1 & 0.32 & 2.9 & 0.50 & 0.18 & 0.26 & 0.08 & 0.03 \\
0.13 & 2.9 & 0.29 & 2.1 & 0.27 & 0.08 & 0.20 & 0.55 & 0.26 \\
$\mathbf{F}$ & & & & & & & & \\
0.02 & 3.4 & 0.37 & 3.8 & 0.45 & 0.20 & 0.26 & 0.07 & 0.02 \\
0.13 & 3.1 & 0.33 & 2.7 & 0.29 & 0.12 & 0.26 & 0.62 & 0.25 \\
$\mathbf{A C}$ & & & & & & & & \\
0.02 & 3.0 & 0.39 & 3.3 & 0.41 & 0.17 & 0.29 & 0.04 & 0.01 \\
0.13 & 3.0 & 0.34 & 2.6 & 0.32 & 0.12 & 0.49 & 0.43 & 0.17 \\
\hline
\end{tabular}

\section{DISCUSSION}

In this study the $\mathrm{M}$ haplotype exhibited 4 characteristics that distinguished it from the native haplotypes: (1) a greater rate of new shoot initiation per gram of rhizome tissue; (2) higher growth rates across the salinity range; $(3)$ the ability to survive and grow at salinities up to $0.40 \mathrm{M} \mathrm{NaCl}$ compared to just $0.13 \mathrm{M} \mathrm{NaCl}$ for native haplotypes; and (4) lower water content in the aboveground tissues. These traits may be interrelated. The rate of shoot elongation in the low salinity treatment was about the same for all haplotypes, but because the $\mathrm{M}$ type initiated more new shoots from rhizomes, it had more shoots and therefore greater biomass production and RGR over the experiment than the other haplotypes. Similarly, the slope of the growth response to salinity from 0.02 to $0.13 \mathrm{M} \mathrm{NaCl}$ was the same for all haplotypes, but because RGR was higher for the $\mathrm{M}$ haplotype, it was able to maintain productivity at higher salinities than the other haplotypes. Lower water content of the $\mathrm{M}$ haplotype contributed to osmotic adjustment of the tissues, as has been reported for other salt tolerant grasses (Glenn 1987, Glenn et al. 1999).

A rapid rate of shoot initiation is advantageous for a plant with a ruderal growth strategy as it can cover bare ground quickly and be more competitive in a mixed stand of plants (Grime 1977). However, rapid shoot initiation would not nec-

Table 4. Examples of invasive species problems in coastal salt marshes. In some cases human activities have resulted in decreased marsh salinities, leading to the invasion of brackish species into salt marshes, where in other cases human activities have resulted in increased salinities, leading to the invasion of halophytes into brackish wetlands

\begin{tabular}{|c|c|c|c|}
\hline Marsh system & Invasive plant problem & Human disturbances & Source \\
\hline $\begin{array}{l}\text { Northern European } \\
\text { coastal marshes }\end{array}$ & $\begin{array}{l}\text { Spartina anglica and other halo- } \\
\text { phytes replacing Phragmites australis }\end{array}$ & $\begin{array}{l}\text { Draining led to increased } \\
\text { marsh salinities }\end{array}$ & $\begin{array}{l}\text { Dijkema (1990), } \\
\text { Esselink et al. (2000) }\end{array}$ \\
\hline $\begin{array}{l}\text { Northwest Pacific } \\
\text { coastal marshes, } \\
\text { US }\end{array}$ & $\begin{array}{l}\text { Spartina alterniflora and other non- } \\
\text { native Spartina spp. replacing native } \\
\text { Spartina foliosa and Salicornia spp. }\end{array}$ & $\begin{array}{l}\text { Non-native Spartina spp. introduced } \\
\text { into San Francisco Bay in the } 1970 \text { s, } \\
\text { now spreading north and south }\end{array}$ & $\begin{array}{l}\text { Daehler \& Strong } \\
\text { (1996), } \\
\text { Hedge et al. (2003) }\end{array}$ \\
\hline $\begin{array}{l}\text { Southern Pacific } \\
\text { coastal marshes, } \\
\text { US }\end{array}$ & $\begin{array}{l}\text { Arundo donax, Polypogon monspeliensis, } \\
\text { Typha domengensis and other brackish } \\
\text { plants replacing native halophytes }\end{array}$ & $\begin{array}{l}\text { Discharge of storm runoff } \\
\text { into marshes led to decreased } \\
\text { marsh salinities }\end{array}$ & $\begin{array}{l}\text { Zedler \& Kercher } \\
(2004)\end{array}$ \\
\hline $\begin{array}{l}\text { Atlantic coastal } \\
\text { marshes, US }\end{array}$ & $\begin{array}{l}\text { Phragmites australis, Juncus gerardii, } \\
\text { Typha angustifolia and other brackish } \\
\text { species replacing Spartina alterniflora }\end{array}$ & $\begin{array}{l}\text { Hydrological alterations of the tide } \\
\text { cycle and discharge of freshwater } \\
\text { runoff has decreased marsh salinities }\end{array}$ & $\begin{array}{l}\text { Rooth et al. (2003), } \\
\text { Konisky \& Burdick } \\
(2004)\end{array}$ \\
\hline $\begin{array}{l}\text { Southeastern } \\
\text { Australia coastal } \\
\text { marshes }\end{array}$ & $\begin{array}{l}\text { Avicennia marina and other mangroves } \\
\text { replacing Sporobolus virginicus } \\
\text { and other salt marsh species }\end{array}$ & $\begin{array}{l}\text { Increased salinity due to altered tidal regimes } \\
\text { and land subsidence due to dredging and } \\
\text { diversion of sediments away from marshes }\end{array}$ & $\begin{array}{l}\text { Saintilan \& Williams } \\
\text { (1999), Vanderzee } \\
\text { (1988) }\end{array}$ \\
\hline
\end{tabular}


essarily be advantageous to plants in a mature stand of Phragmites australis, as the shoots will ultimately compete with each other for sunlight and nutrients. Since $P$. australis in a mature stand propagates clonally from rhizomes, excess shoot initiation would represent a form of self-competition. Therefore, the $M$ haplotype appears to be adapted to a weedy growth strategy, which would be expected to lead to heightened ability to colonize new areas or to gain a foothold in stands of other marsh vegetation.

As noted in other studies with Phragmites australis, the majority of the osmotic adjustment could be attributed to the high $\mathrm{K}^{+}$content of the shoot tissues for all haplotypes (Glenn 1987, Matoh 1988), although $\mathrm{Na}^{+}$ and the Na:K ratio increased with salinity. In contrast, Spartina spp. and other halophytic grasses achieve the greatest part of their osmotic adjustment by accumulating $\mathrm{Na}^{+}$plus balancing anions (Glenn 1987, Glenn et al. 1999, Bell \& O'Leary 2003). Lissner \& Schierup (1997) found that both osmotic pressure and chlorinity of the tissues of roots and leaves increased in proportion with a rise in salinity up to $0.43 \mathrm{M} \mathrm{NaCl}$ for rhizome-grown $P$. australis plants. They found that plants grown from seeds were less salt-tolerant than plants grown from rhizomes, and that the leaves of these plants exhibited marked increases in osmotic pressure and loss of turgor at salinities above $0.26 \mathrm{M} \mathrm{NaCl}$. Increases in amino acids in rhizomes and sugars in leaves have been shown in response to increased salinity by clones of $P$. australis (Hartzendorf \& Rolletschek 2001). They found that these organic compounds contributed 13 to $15 \%$ of the total osmolality at $0.18 \mathrm{M} \mathrm{NaCl}$, whereas inorganic cations and anions contributed the rest.

Although the haplotypes appeared to share a common mechanism of osmotic adjustment $\left(\mathrm{K}^{+}\right.$accumulation), the greater growth potential of the $\mathrm{M}$ haplotype resulted in much greater growth and survival at salinities higher than 0.13 $\mathrm{M}$ for the $\mathrm{M}$ haplotype compared to the native haplotypes. Intraspecies differences in salt tolerance have been reported for many plant species, including glycophytes (reviewed in Shannon \& Grieve 1999) and halophytes (reviewed in Glenn et al. 1999). However, the degree of difference between the $M$ haplotype and the native haplotypes is remarkable. In contrast, studies of salt tolerance of Mediterranean populations of Phragmites australis revealed little ecotypic differentiation among populations with regard to growth response to salinity (Mauchamp \& Mesleard 2001).

Though salt tolerance is low for the American haplotypes of Phragmites australis, higher salinity tolerances are known from populations in other areas including those from Europe and Asia, where the $M$ haplotype evolved. For example, greenhouse studies of popula- tions of $P$. australis from Denmark showed that $75 \%$ of rhizome-grown plants survived at a salinity of $0.4 \mathrm{M}$ (Lissner \& Schierup 1997). Soetaert et al. (2004) recorded good growth of $P$. australis in the Scheldt estuary, Netherlands, up to $0.2 \mathrm{M}$. They also noted that under salt stress, the plants developed numerous shoots with smaller leaves compared to unstressed plants. Other saline-tolerant populations of $P$. australis have been noted from Asia (e.g. Matoh et al. 1988).

The salinity tolerance range of the $M$ haplotype is well within the salinity range found in coastal Spartina marshes, especially those with some fresh water influx (e.g. Farnsworth \& Meyerson 2003, Silliman \& Bertness 2004). In greenhouse trials similar to those conducted here (Glenn 1987), S. longispica had a $70 \%$ reduction in RGR from 0 to $0.52 \mathrm{M} \mathrm{NaCl}$, similar to the rate of reduction recorded for the $M$ type in the present experiment (i.e. $13.5 \%$ reduction in RGR per $0.1 \mathrm{M}$ $\mathrm{NaCl}$ for both species). Because of the salt tolerance of the Eurasian M haplotype, it has been able to successfully colonize habitat that was not formerly available to Phragmites australis in this region.

These experiments help explain how the M haplotype of Phragmites australis differs in growth characteristics from the native haplotypes, allowing it to become invasive in coastal Spartina marshes. The genetic and enzymatic mechanisms underlying these differences remain to be explored. Furthermore, breeding barriers between haplotypes presumably exist for them to maintain discrete populations, and these also remain to be explored. Other factors may also contribute to the spread of the $M$ haplotype. For example, the different growth habits of the haplotypes may affect their ability to ventilate the soil by conducting air to the rhizomes, which is dependent on the cross-sectional area of the shoots (Rolletschek et al. 1999), a factor that differed among haplotypes (see Fig. 1). Additional, fundamental differences in intrinsic photosynthetic efficiency, ratio of photosynthetic to non-photosynthetic tissue, and other ecophysiological characteristics may exist among the haplotypes that contribute to their niche specializations.

The role of salt tolerance in the invasion of the M haplotype of Phragmites australis into Spartina alterniflora marshes on the Atlantic coast of North America is most likely being replayed in a number of interactions between brackish and saltwater plant species in marshes around the world. In nearly all of these cases, the stage is set by the introduction of new species and the concomitant alteration of marsh habitats by humans (Table 1) (Adam 2002, Zedler \& Kercher 2004). Some alterations increase salinities in the marshes, leading to the replacement of brackish species with more salt-tolerant species, whereas other alterations reduce marsh salinities, leading to the 
spread of brackish species into salt marshes. Interestingly, the roles of invader and resident are reversed in some areas. For example, the problem in northern European salt marshes is the invasion of Phragmites australis marshes by Spartina spp. (Dijkema 1990, Esselink et al. 2000), a situation opposite to that of North America. The North American marsh grass $S$. alternifolora was introduced into Europe in the 19th century, where it hybridized with the local species of Spartina (S. maritima) to form $S$. townsendii and $S$. anglica, 2 new species (Adam 2002). These new species are now expanding into European $P$. australis marshes, where they are considered invasive. The expansion of the salt-tolerant Spartina species was facilitated by alteration of the marshes with drainage canals that has resulted in increasing salinities, allowing the Spartina spp. to obtain footholds. A similar scenario is found on the northwest coast of the United States (Daehler \& Strong 1996). There, in the 1970s, $S$. alterniflora from the Atlantic coast of North America was introduced to the Pacific coast, where it has become invasive in Salicornia salt marshes. Even species such as mangroves that have high conservation value in most places are considered invasive species in southeastern Australia (Saintilan \& Williams 1999) and Hawaii (Sauer 1988). Hence, 'invasiveness' appears not to be a property of an individual species but must be regarded as a context-specific process of plant-plant and plant-environment interactions (Zedler \& Kercher 2004).

Acknowledgements. This study was supported through funding from the U.S. Geological Survey (USGS)/U.S. Fish and Wildlife Service (USFWS), Science Support Partnership Program. The authors thank the following individuals for their assistance: James Lynch, USGS; Robert Meadows and Bill McAvoy, Delaware Division of Natural Resources; Matthew Jones, Delaware State University; and Kristin Saltonstall, Horn Point Laboratory, University of Maryland.

\section{LITERATURE CITED}

Able K, Hagan S (2003) Impact of common reed, Phragmites australis, on essential fish habitat: influence on reproduction, embryological development, and larval abundance of mummichog (Fundulus heteroclitus). Estuaries $26: 40-50$

Able K, Hagan S, Brown S (2003) Mechanisms of marsh habitat alteration due to Phragmites: response of youngof-the-year mummichog (Fundulus heteroclitus) to treatment for Phragmites. Estuaries 26:484-494

Adam P (2002) Saltmarshes in a time of change. Environ Conserv 29:39-61

Bart D, Hartman J (2003) The role of large rhizome dispersal and low salinity windows in the establishment of common reed, Phragmites australis, in salt marshes: new links to human activities. Estuaries 26:436-443
Bell H, O'Leary J (2003) Effects of salinity on growth and cation accumulation of Sporopolus virginicus (Poaceae). Am J Bot 90:1416-1424

Burdick D, Konisky R (2003) Determinants of expansion for Phragmites australis, common reed, in natural and impacted coastal marshes. Estuaries 26:407-416

Chambers R, Osgood M, Bart D, Montalto F (2003) Phragmites australis invasion and expansion in tidal wetlands: interactions among salinity, sulfide, and hydrology. Estuaries 26:398-406

Cronk J, Fennessy M (2001) Wetland plants: biology and ecology. Lewis Publishers, Boca Raton, FL

Currin C, Wainright, A, Able K, Weinstein M, Fuller C (2003) Determination of food web support and trophic position of the mummichog, Fundulus heteroclitus, in New Jersey smooth cordgrass (Spartina alterniflora), common reed (Phragmites australis), and restored salt marshes. Estuaries 26:495-510

Daehler C, Strong D (1996) Status, prediction and prevention of introduced cordgrass Spartina spp. invasions in Pacific estuaries, USA. Biol Conserv 78:51-58

Dijkema K (1990) Salt and brackish marshes around the Baltic Sea and adjacent parts of the North Sea: their vegetation and management. Biol Conserv 51:191-209

Esselink P, Zijlstra W, Dijkema K, van Diggelen R (2000) The effects of decreased management on plant-species distribution patterns in a salt marsh nature reserve in the Wadden Sea. Biol Conserv 93:61-76

Farnsworth E, Meyerson L (2003) Comparative ecophysiology of four wetland plant species along a continuum of invasiveness. Wetlands 23:750-762

Glenn E (1987) Relationship between cation accumulation and water content of salt tolerant grasses and a sedge. Plant Cell Environ 10:205-212

Glenn E, Brown J, Blumwald E (1999) Salt tolerance and crop potential of halophytes. Crit Rev Plant Sci 18:227-255

Grime J (1977) Evidence for the existence of three primary strategies in plants and its relevance to ecological and evolutionary theory. Am Nat 111:1169-1194

Hartzendorf T, Rolletschek $\mathrm{H}$ (2001) Effects of $\mathrm{NaCl}$ salinity on amino acid and carbohydrate contents of Phragmites australis. Aquat Bot 69:195-208

Havens K, Berquist H, Priest W (2003) Common reed grass, Phragmites australis, expansion into constructed wetlands: Are we mortgaging our wetland future? Estuaries 26:417-422

Hedge P, Kriwoken L, Patten K (2003) A review of Spartina management in Washington State, US. J Aquat Plant Manag 41:82-90

Konisky R, Burdick B (2004) Effects of stressors on invasive and halophytic plants of New England salt marshes: a framework for predicting response to tidal restoration. Wetlands 24:434-447

Lathrop R, Windham G, Montesano P (2003) Does Phragmites expansion alter the structure and function of marsh landscapes? Patterns and processes revisited. Estuaries 26: 423-435

Lissner J, Schierup H (1997) Effects of salinity on the growth of Phragmites australis. Aquat Bot 55:247-260

Lynch E, Saltonstall K (2002) Paleoecological and genetic analyses provide evidence for recent colonization of native Phragmites australis populations in a Lake Superior wetland. Wetlands 22:637-646

Matoh T, Matsushita N, Takahashi E (1988) Salt tolerance of the reed plant Phragmites australis communis. Physiol Plant 72:8-14

Mauchamp A, Mesleard F (2001) Salt tolerance in Phragmites 
australis populations from coastal Mediterranean marshes. Aquat Bot 70:39-52

Ravit B, Ehrenfield J, Haggblom M (2003) A comparison of sediment microbial communities associated with Phragmites australis and Spartina alterniflora in two brackish wetlands of New Jersey. Estuaries 26:465-474

Rolletschek H, Harzendorf T, Rolletscheck A, Kohl J (1999) Biometric variation in Phragmites australis affecting convective ventilation and amino acid metabolism. Aquat Bot 64:291-302

Rooth J, Stevenson J, Cornwell J (2003) Increased sediment accretion rates following invasion by Phragmites australis: the role of litter. Estuaries 26:475-483

Saintilan N, Williams, R (1999) Mangrove transgression into saltmarsh environments in south-east Australia. Glob Ecol Biogeogr 8:117-124

Saltonstall K (2002) Cryptic invasion by a non-native genotype of the common reed, Phragmites australis, into North America. Proc Natl Acad Sci 99:2445-2449

Saltonstall K (2003a) A rapid method for identifying the origin of North American Phragmites populations using RFLP analysis. Wetlands 23:1043-1047

Saltonstall K (2003b) Genetic variation among North American populations of Phragmites australis: implications for management. Estuaries 26:441-451

Saltonstall K, Peterson P, Soreng R (2004) Recognition of Phragmites australis subsp. americanus (Poaceae: Arundinoideae) in North America: evidence from morphological and genetic analyses. SIDA Contrib Bot 21:683-692

Sauer J (1988) Plant migration. The dynamics of geographic patterning in seed plant species. University of California Press, Berkeley, CA

Editorial responsibility: Victor de Jonge (Contributing Editor), Haren, The Netherlands
Shannon M, Grieve C (1999) Tolerance of vegetable crops to salinity. Sci Horic (Amst) 78:5-38

Silliman B, Bertness M (2004) Shoreline development drives invasion of Phragmites australis and the loss of plant diversity on New England salt marshes. Conserv Biol 18: $1424-1434$

Soetaert K, Hoffman M, Meire P, Starink M, van Oevelen D, Van Regenmortel S, Cox T (2004) Modeling growth and carbon allocation intwo reed beds (Phragmites australis) in the Scheldt estuary. Aquat Bot 79:211-234

Vanderzee M (1988) Changes in saltmarsh vegetation as an early indication of sea-level rise. In: Pearman G (ed) Greenhouse. Planning for climate change. CSIRO, Collingwood, p $147-160$

Weinstein M, Keough J, Guntenspergen G, Litvin S (2003) Preface: Phragmites australis: a sheep in wolf's clothing. Estuaries 26:397

Weis J, Weis P (2003) Is the invasion of the common reed, Phragmites australis, into tidal marshes of the eastern US an ecological disaster? Mar Pollut Bull 46: $816-820$

Weis J, Windham S, Weis P (2003) Patterns of metal accumulation in leaves of the tidal marsh plants Spartina alterniflora and Phragmites australis cav. Trin ex steud. over the growing season. Wetlands 23:459-465

Windham L, Meyerson L (2003) Effects of common reed (Phragmites australis) expansions on nitrogen dynamics of tidal marshes of the northeastern US. Estuaries 26: 452-464

Zedler J, Kercher S (2004) Causes and consequences of invasive plants in wetlands: opportunities, opportunists, and outcomes. Crit Rev Plant Sci 23:431-452

Submitted: October 5, 2004; Accepted: May 16, 2005

Proofs received from author(s): July 4, 2005 